\title{
The Role of Organizational Factors of Empowerment and Motivation in Enhancing Employees' Commitment in Indian Automotive Industry
}

\author{
Manisha Sharma*, Monika Bhati \\ Gautam Buddha University, Greater Noida, India
}

Copyright $\bigcirc 2017$ by authors, all rights reserved. Authors agree that this article remains permanently open access under the terms of the Creative Commons Attribution License 4.0 International License

\begin{abstract}
Studies show that positive feelings and perception of the employees about the various aspects of their job and employment lead to higher organizational commitment which indicates that it is the psychological capability of an employee that is related to the intrinsic Employees' empowerment, recognized as an effective management technique which can universally be adopted by business organizations to improve organizational relationship, identification, performance and productivity. Researchers have conducted numerous studies to understand the nature and dimensions of empowerment. In this context this article aims to investigate the role of organizational empowerment and motivation factors in enhancing the employees' commitment as measured by affective, continuous and normative commitment in the automotive industry in India. A random sample size of 242 employees from Indian Automotive Industry consisting of two automobile and two auto-component companies was taken to participate in data collection from NCR (National Capital Region), India. Data analyzed using linear regression analysis showed positive relationship between organizational factors of empowerment \& motivation and employees' commitment.
\end{abstract}

\section{Keywords Empowerment, Motivation, Affective Commitment, Continuous Commitment, Normative Commitment, Indian Automotive Industry}

\section{Introduction}

The present research is focused on exploring the various aspects of managing the employees' commitment for ensuring sustained productivity in automotive sector that has displayed a noteworthy growth pattern during last few decades and now occupies a place of prime importance in India's economy. However, the image of the industry has got blurred due to frequent incidences of employees' protests and strikes. It indicates that some basic differences must be existing between the views of the organization, leadership and the employees regarding the relevance of certain organizational policies. It may be stressed that if in any organization the employees lose trust in the leadership motives or develop a feeling of being ignored; their impaired sensibilities may create grave consequences for the organizational climate and relations. Thus the employees' perception regarding the effectiveness of the organizational policies goes a long way in shaping their attitude towards the organizational values, vision and objectives. Thus a need is felt to discover the role of intrinsic motivation and empowerment in enhancing the commitment of employees towards the organization in Automotive Industry.

\section{Empowerment and Motivation: The Conceptual Analysis}

From the various studies conducted in hope of improving employee's commitment across various sectors, it has been found that motivated \& empowered employees were more committed to the organization. Kreitner [1] has suggested that motivation is a psychological process that gives a purpose and direction to an individual's behavior. Grant [2] observed that certain employees often go above and beyond the call of duty and persist in performing their work effectively and productively even in absence of any personal gain. A study conducted by Cooper \& Robinson [3] revealed that providing choice is positively related with intrinsic motivation, task performance and perceived competence. The study conducted by Yazani et.al. [4] evaluated the role and relevance of job-assignment, performance based rewards, participative-management, self-determination and participation in goal setting as main ways of empowerment and found that empowered employees consider their job and work life more purposeful and meaningful. 
According to the studies conducted by Hamed, Naqvi et al. and Sahoo ([5-7]), it was concluded that a positive relationship exists between psychological empowerment and organizational factors i.e.: personal growth, organizational trust, reward, recognition and leadership support that leads to reinforcing the organizational commitment (Naqvi et al.; Rawat [6,8]). Whereas Laschinger et al. [9] found that changes in perceived structural empowerment had direct effects on changes in psychological empowerment and job satisfaction. The results further suggested that fostering environments that enhance perceptions of empowerment can have enduring positive effects on employees. Bux \& Tay [10] worked on the the relationship between psychological empowerment, talent engagement and talent outcomes, and identify possible associations between the dynamics of psychological empowerment and the effects of talent engagement by linking the measures of psychological empowerment to talent engagement could bring about better understanding on the underlying reasons on what drives employees. Thus Empowerment is essentially a process which enables an individual feel competent and confident about his work and thereby there is a need to identify its parameters which this study tries to explore further.

\section{Indian Automotive Industry: The Current Scenario}

In the present scenario of global competitiveness, India has emerged as a well-recognized source of manufacturing high quality engineering products. The automotive industry being one of the largest industries, occupies the place of key driver in nation's economic growth. Since the removal of trade restrictions in 1991, the Indian automotive sector has shown a robust growth pattern and is now considered as a dependable industry in international market.

Currently the automotive industry in India is producing a wide range of vehicles such as $\mathrm{s}$ passenger cars, light medium and heavy commercial vehicles, multi-utility vehicles such as jeeps, scooters, motor cycles etc. three wheelers, tractors and other agriculture equipment. The industry now ranks eleventh in production of passenger cars; fourth in commercial vehicles and second in two wheelers. It is now growing at a compounded annual growth of approximately $17 \%$. Since the automotive industry is effectively linked with other segments of economy it has a strong multiplier effect on the national economy.

Along with the manufacturing of different kinds of vehicles the automotive components manufacturing is another equally important segment of the automotive sector. According to the vision document of auto component manufacturing association document, the global auto component industry is likely to become US $\$ 1.9$ trillion by 2015 of which the Indian component of industry is expected to touch US\$40 billion (ACMA-McKinsey Vision 2015 [11]).
The Indian Government has prepared a policy document in collaboration with the automotive industry and academic called Automotive Mission Plan (AMP) 2016-26[12], which envisages that "AMP 2026 will help Automotive Industry to focus on its strengths and improve its competitiveness in select segments, achieve the annual production target of Rs. $16,16,000$ cr. to Rs. $18,89,500$ cr. in terms of its size and establish its 'Right to Win' on the global stage.

With the rapid pace of technical progress and global competition the Indian automotive industry has adopted the advanced manufacturing technology (AMT) and lean production process, which has helped in integrating the Indian automotive industry with global production network. However such adoptions also have implications for other issues concerning the labour process, skill and working conditions (Jha \& Chakraborty [13]). This makes the management's role in maintaining employees' commitment for achieving the organizational goals quite crucial. If at any stage the employees lose their trust in the leadership- motives or develop the feeling of being ignored in decision making process, their impaired sensibilities often create grave consequences for smooth functioning of the industry.

\subsection{Role of Empowerment and Motivation in Automotive Industry}

In today's competitive environment, the automotive industry is more concerned about the survival, growth and maximum use of the potential of its workforce. To achieve such objectives the majority of labor force employed in automotive industry is on contract basis but it is quite obvious that these employees, who besides not having any job-security or opportunity for competency development, are also deprived of any type of operational autonomy or any role in the decision making process, do not derive any pride in their work.

Enormous organizations are built on the inherent value of their employees as motivated and committed employees almost always allow an organization to grow faster than similar competitive organizations. Motivated and Empowered employees with high levels of commitment are considered to be the most important asset for any organization (Shore \& Martin; Richard et al. [14,15]) and keeping the employee motivation, and empowerment up is always rewarding to an industry as motivated and committed employees are more productive and higher productivity usually results in higher profits (Denton [16]) .

Employees' organizational factors of motivation and empowerment are intimately associated with employees' identification, commitment, performance and productivity (Ashforth \& Mael; Pratt; Manzoor [17-19]). Researchers have suggested that employee empowerment and motivation are positively associated with employees' participation, job satisfaction, organizational commitment and higher productivity (Mullins \& Peacock; Kirkman \& Rosen; Doughty; Kuo Ho Lin \& Lai; Iqbal et al. [20-24]). 
Thus the present study attempts to examine the inter-linkages between various factors associated with managing the employees' commitment in Indian automotive industry.

The article is structured as follows: we introduce the theoretical development and subsequent hypotheses in the third section. The fourth section presents analysis and results, followed by discussions and scope for future research in the concluding section.

\section{Theoretical Development and Hypotheses Generation}

Studies have been conducted to explore the relationship between empowerment and certain factors that are considered as antecedents of organizational commitment such as: personal growth, job satisfaction and organizational trust (Hamed [5]), reward and recognition (Bogler \& Somech [25] and leadership support (Naqvi et al; Sahoo [6,7]). These studies concluded that a positive relationship exists between psychological empowerment and these factors Hamed [5] that leads to reinforcing the organizational commitment (Naqvi et al.; Rawat [6,8]). The linkage between psychological empowerment and factors of organizational commitment was also examined by Jha [26] in context of IT industry. The study revealed that although no relationship exists between psychological empowerment and continuance commitment, there exists a positive relationship between employees' empowerment and the affective and normative commitments.

Numerous scholars have conducted research to identify the factors affecting empowerment. The study conducted by Yazdani et al. [4] evaluated the role and relevance of job-assignment, performance based rewards, participative-management, self-determination and participation in goal setting as main ways of empowerment and found that empowered employees consider their job and work life more purposeful and meaningful.

Therefore it may be comprehended that the firms need to focus on certain organizational factors that determine the employees' empowerment and motivation and thereby increase their organizational commitment.

\subsection{Determinants of Organizational Factors of Motivation and Empowerment}

Researchers have conducted numerous studies to understand the nature and dimensions of motivation and empowerment. According to the researchers (Mottaz; Wong \& Tsang; Bakay \& Huang [27-29]), there are two motivating factors of job, separated as an intrinsic and extrinsic variable. Wong \& Tsang [28], says that the intrinsic variables contain feelings of involvement, interesting work, career development and promotion and the extrinsic variables are job security, respectable salary, thoughtful discipline, and good working conditions

However in the motivational approach, empowerment is considered as a psychological capability and intrinsic motivation of an individual employee (Curtis et al. [30]). Some researchers conceptualized the psychological empowerment as a multidimensional motivational construct consisting of four cognitive dimensions namely meaning or purpose, competence, self-determination and impact which combined together are indicative of the basic essence of employees' empowerment at work place (Spreitzer; Thomas $\&$ Velthouse [31,32]). According to structural approach, the term empowerment is associated with granting a role to concerned employees' participation in decision making process (Kanter; Thorlkson \& Murray; Ongori \& Shunda; Judith [33-36]).

Numerous scholars have conducted research to identify the factors affecting empowerment. Frankl [37] analyzed the performance of the people at work place. He found that having a purpose of life is the basic motivation that is related to an individual search for finding meaning in life. It may be appreciated that when employees find meaning in work, they display positive organizational behavior leading to affective organizational relationship, commitment and performance. A study conducted by Tempoe [38] identified three key motivators viz., personal growth, operational autonomy and task achievement that create a feeling of personal and professional achievement thereby reinforcing the individuals' sense of being purposeful and significant.

The meaning of motivation \& empowerment for employees is manifest. Jha [26] explored the linkage between psychological empowerment and factors of organizational commitment in context of IT industry. The study revealed that there exist a positive relationship between employees' empowerment and the affective and normative commitments. Hamed [5] examined the relationship between empowerment and certain factors which are considered as antecedents of organizational commitment such as: personal growth, job satisfaction and organizational trust reward and recognition (Bogler \& Somech [25]) and leadership support (Naqvi et al.; Sahoo $[6,7])$. These studies concluded that a positive relationship exists between psychological empowerment and these factors that lead to reinforcing the organizational commitment (Naqvi et al.; Rawat $[6,8]$ ). If employees are given freedom to participate in decision making process and provided full autonomy to do their job which is challenging as well, they feel motivated and empowered to do work and thereby actively get involved and attached with the work and the objective of the organization.

\subsubsection{Scale Development for Organizational Factors of Empowerment and Motivation: Factor Analysis}

The set of 12 questions for conducting the survey was initially formulated on the basis of the various reviews (Hamed; Naqvi et al.; Sahoo; Rawat; Bogler \& Somech; Jha, $[5-8,25,26])$ to measure organizational factors of 
Empowerment and Motivation, which was further subdivided into the factors with the help of factor analysis.

Factor analysis was conducted to deduce factors of Empowerment and Motivation. Liu \& Lan [39] examined factor analysis as a technique to simplify the data which studies the inner dependent relationship of many variables and probes into the basic structure of observing data and uses several hypothetical variables to represent the basic data structure. Before applying the analysis, KMO \& Bartlett's test has been run to see the suitability of Factor Analysis. $\mathrm{KMO}$ measure of sampling adequacy is 0.843 which shows that Factor Analysis is significant for this data.

Table 1 shows that 12 leading indicators can be divided into four components called as factors because the Eigen values of these four factors are greater than 1 where as rest of the factors have been ignored because their Eigen values are less than 1 . The total variance explained by these four factors is $83.227 \%$ which meets the requirements for the number of factors and contribution rate. The criterion for variance analysis is usually that the accumulated contribution rate should reach $80 \%$ (Chen [40]). Therefore, the four common factors namely F1, F2, F3 and F4 are chosen to describe the indicators.

Table 1. The variance contribution of the dominant factors

\begin{tabular}{|c|c|c|c|}
\hline \multirow{2}{*}{ Component } & \multicolumn{3}{|c|}{ Rotation Sums of Squared Loadings } \\
\cline { 2 - 4 } & Total & \% of Variance & Cumulative \% \\
\hline 1 & 3.249 & 27.822 & 27.822 \\
\hline 2 & 2.823 & 22.172 & 49.994 \\
\hline 3 & 2.811 & 21.017 & 71.011 \\
\hline 4 & 1.907 & 16.049 & 87.016 \\
\hline
\end{tabular}

In order to show the contribution rate of each indicator of every factor more clearly, this paper adopts the variance maximum (Varimax) rotation, so that the absolute values of factor loadings are in polarization from 1 to 0 by columns, and get the factor loading matrix after the rotation which is presented in the Table 2 representing the rotated factor matrix which explains the correlation between the indicators and the related factor. The indicators have been divided into four factors based on their correlation values and hence the factor 1 consists of those attributes having the contribution rate of greater than $65 \%$ (Wang [41]), same is the criteria for the other factors.

According to the Table 2, considering the principle of contribution rate $\geq 65 \%$ the value of $F 1$ is larger in $X_{1}, X_{2}$ and $X_{3}$, the value of $F 2$ is larger in $X_{4}, X_{5}$ and $X_{6}$, the value of $\mathrm{F} 3$ is larger in $\mathrm{X}_{7}, \mathrm{X}_{8}$ and $\mathrm{X}_{9}$ and the value of $\mathrm{F} 4$ is larger in $\mathrm{X}_{10}, \mathrm{X}_{11}$ and $\mathrm{X}_{12}$. Indicators closely related with $\mathrm{F} 1$ are about the support from the organization. So here, we define F1 as the Organizational Support. Indicators closely related with F2 are about the challenges inherent in the jobs which motivate a particular employee towards performing better. So here, we define F2 as the Job Challenge factor. Indicators closely related with F3 are about the autonomy which an employee seeks while delivering the job. So here, we define F3 as Operational Autonomy factor. Indicators closely related with F4 are about the flow of communication between the management and the employees which may cultivate the confidence in employees. So here, we define F4 as the Open Communication factor. These four factors also show the hierarchal presentation of the components according to their importance. Organizational Support factor is found the most important factor while the Operational Autonomy factor takes the last position in the order of importance although the difference is negligible as all the four factors are considered to be very important by the employees.

Table 2. The rotated factor loading matrix

\begin{tabular}{|c|c|c|c|c|}
\hline & 1 & 2 & 3 & 4 \\
\hline My superiors recognition of my consistent efforts enhances my self-esteem (OF1) & .985 & & & \\
\hline $\begin{array}{l}\text { The support provided by superiors in adverse circumstances inspires me to take up challenging } \\
\text { assignments (OF2) }\end{array}$ & .891 & & & \\
\hline The organizational support for conducting experimentation motivates me to involve in creative ventures & .880 & & & \\
\hline I like to do challenging assignments with some element of newness & & .830 & & \\
\hline The challenging job assigned by my organization enhances my confidence in my abilities & & .954 & & \\
\hline I like to work in my organization because it provides opportunity to do challenging tasks & & .757 & & \\
\hline The autonomy provided by the organization in conducting job encourage me for better performance & & & .833 & \\
\hline The flexibility provided by the organization in working norms enhances my creative urge & & & .803 & \\
\hline $\begin{array}{l}\text { The opportunities provided by the organization to conduct a job in my own way reinforces my sense of } \\
\text { responsibility }\end{array}$ & & & .724 & \\
\hline $\begin{array}{l}\text { My superiors encouragement for suggesting new ideas to solve a problem motivates me to assume } \\
\text { responsibility }\end{array}$ & & & & .968 \\
\hline
\end{tabular}


Thereby the organizational factors of Motivation and Empowerment chosen for this study are: Job Challenge, Operational Autonomy, Open Communication and Organizational Support.

\subsection{Determinants of Organization Commitment}

Commitment is an important instrument for enhancing the performance of the employees. The Researches conducted on commitment have shown that the employees committed to their organization indicate positive attitude towards their organizational goals which ultimately results in higher organizational performance and enhanced productivity (Arthur; Steers; Chen et al. [42-44]) have found that the organizational commitment may be positively related with various outcomes such as employees' job satisfaction, motivation and performance, and may be negatively correlated to absenteeism and turnover. Thomas \& Velthouse [32] found that commitment is motivated by purpose to work smart, take personal responsibility for making things happen and apply intelligence to getting activities or tasks accomplished.

Mowday et al. [45] stated that employee's commitment is a psychological attachment of an employee with the organization that depends on the degree of employee's motivation, involvement, loyalty, and trust in the values and norms of the organization. According to Allen \& Meyer [46], organizational commitment can be classified into three main components that are affective commitment (AC), continues commitment (CC) and normative commitment (NC), which may be considered as a reference framework for organizational commitment. Thereby employees' commitment of the automotive industry was measured by using Richard et al. [15].

\subsection{Research Framework}

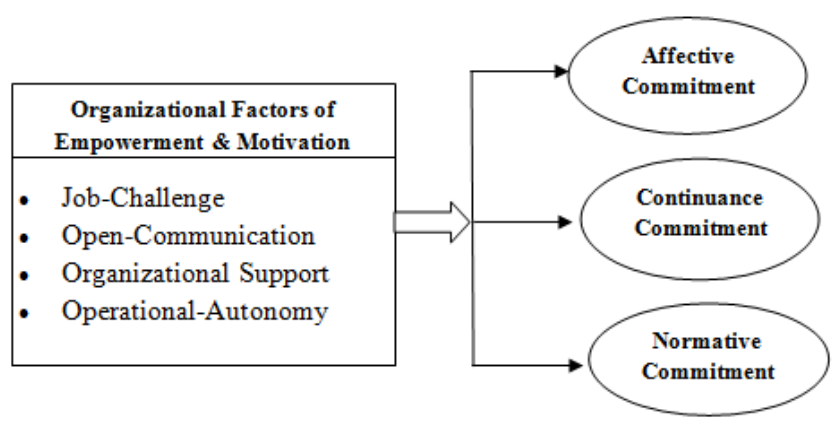

Figure 1. Research Framework

This paper is focused on as to examine the relationship between organizational factors of motivation \& empowerment and the organizational commitment measured by affective, continuance and normative commitment as in the Indian automotive industry. The main research question of this paper can be restated as 'Do organizational factors of motivation \& empowerment influence the organizational commitment of the employees (i.e. affective, continuance and normative) in the Indian automotive industry?

Thus we offer the following hypotheses:

$\mathrm{H}_{1}$ : The organizational factors of motivation and empowerment are positively associated with the employees' affective commitment.

$\mathrm{H}_{2}$ : The organizational factors of motivation and empowerment are positively associated with the employees' continuance commitment.

$\mathrm{H}_{3}$ : The organizational factors of motivation and empowerment are positively associated with the employees' normative commitment.

The organizational factors of Motivation and Empowerment chosen for this study were measured through Job Challenge, Operational Autonomy, Open Communication and Organizational Support as derived with the help of factor analysis via a 24-item measure (four items for each scale) whereas employees' commitment of the automotive industry was measured by using Richard et.al. [10] with a 12-item measure of affective, continuance and normative commitment (four items in each scale). The respondents were provided 5 choices viz., strongly agree (SA), agree (AG), neither agree nor disagree (NA), disagree (DA) and strongly disagree (SD) with their relative weights varying from 5 for strongly agree to 1 for strongly disagree recorded and measured on Likert scale. These sets of questions were distributed to 400 employees working in the Indian Automotive Industry which included two automobile and two auto-component companies situated in NCR, India. The number of fully filled up 242 responses were selected for the analysis. The total number of respondents indicating a specific choice against a statement was evaluated.

\section{Data Analysis: The Regression Analysis}

The regression analysis was conducted to assess the influence of the organizational factors of motivation and empowerment viz., job-challenge, operational-autonomy, open-communication and organizational-support on the dependent variable: organizational commitment. The organizational commitment was measured through three parameters: normative, continuous and affective commitment.

The Table 3 shows the details of analysis indicating the impact of the motivational and empowering factors on employees' affective commitment. The analysis shows that all the factors of the employees' motivation and empowerment viz., job-challenge $(\mathrm{p}=0.027)$, operational-autonomy $\quad(\mathrm{p}=0.000), \quad$ open-communication $(\mathrm{p}=0.000)$ and organizational-support $(\mathrm{p}=0.000)$ are positive predictors of the affective commitment. 
Table 3. Employees' Motivation \& Empowerment on Affective Commitment

\begin{tabular}{|c|c|c|c|c|}
\hline \multirow{2}{*}{ Model } & \multicolumn{2}{|c|}{ Unstandardized Coefficients } & \multirow{2}{*}{$\begin{array}{c}\text { Standardized } \\
\text { Coefficients }\end{array}$} & \multirow{2}{*}{ Sig. } \\
\hline & B & Std. Error & & \\
\hline (Constant) & -.387 & .188 & & .041 \\
\hline Job- Challenge & -.600 & .270 & -.399 & 0.027 \\
\hline Operational-Autonomy & 1.819 & .126 & -1.371 & 0.000 \\
\hline Open-Communication & .883 & .232 & .597 & 0.000 \\
\hline Organizational-Support & -1.043 & .140 & -.671 & 0.000 \\
\hline
\end{tabular}

Source: Prepared by the authors

Table 4. Employees' Motivation \& Empowerment on Continuance Commitment

\begin{tabular}{|c|c|c|c|c|}
\hline \multirow{2}{*}{ Model } & \multicolumn{2}{|c|}{ Unstandardized Coefficients } & \multirow{2}{*}{$\begin{array}{c}\begin{array}{c}\text { Standardized } \\
\text { Coefficients }\end{array} \\
\text { Beta }\end{array}$} & \multirow{2}{*}{ Sig. } \\
\hline & B & Std. Error & & \\
\hline (Constant) & -.277 & .101 & & .007 \\
\hline Job- Challenge & -.222 & .145 & -.187 & .127 \\
\hline Operational-Autonomy & .749 & .068 & .716 & .000 \\
\hline Open-Communication & .337 & .125 & .289 & .007 \\
\hline Organizational-Support & .203 & .075 & .165 & .007 \\
\hline
\end{tabular}

Source: Prepared by the authors

Table 5. Employees' Motivation \& Empowerment on Normative Commitment

\begin{tabular}{|c|c|c|c|c|}
\hline \multirow{2}{*}{ Model } & \multicolumn{2}{|c|}{ Unstandardized Coefficients } & \multicolumn{2}{c|}{$\begin{array}{c}\text { Standardized } \\
\text { Coefficients }\end{array}$} \\
\cline { 2 - 5 } & $\mathbf{B}$ & Std. Error & \multicolumn{2}{c|}{ Beta } \\
\hline (Constant) & $\mathbf{- . 5 2 5}$ & $\mathbf{. 1 9 1}$ & .229 & .207 \\
\hline Job-Challenge & -.347 & .274 & 1.333 & .000 \\
\hline Operational-Autonomy & 1.776 & .128 & .394 & .014 \\
\hline Open-Communication & .586 & .236 & -.592 & .000 \\
\hline Organizational-Support & -.924 & .142 & & \\
\hline
\end{tabular}

Source: Prepared by the authors

It validates the hypothesis 1 which says that all the factors of motivation and empowerments (viz., job-challenge, operational-autonomy, open-communication and organizational-support) contribute in developing the synergy between an individual's own values and organization values that ensures his total involvement and commitment for achieving organizational objectives.

Table 4 provides the finding of data-analysis regarding the impact of the factors of motivation and empowerment on employees' continuance commitment. It is found that three factors viz., operational-autonomy $\quad(\mathrm{p}=0.000)$, open-communication $(\mathrm{p}=0.007)$ and organizational-support $(\mathrm{p}=0.007)$ have a strong impact on the continuance commitment whereas Job Challenge $(\mathrm{p}=0.127)$ does not contribute to the continuance commitment of an employee.

Thus an individual's desire to stay in organization is largely influenced by the operational-autonomy that enhances an individual's self-efficacy, open-communication that indicates the leadership trust and organizational-support for involving in innovative ventures. The assignment of challenging job per se is not an important factor in influencing one's decision to stay with the organization as nobody expects that the organization he decides to join will not assign him job according to the level of skills and abilities.

Table 5 details the impact of the employees' empowerment and motivation on the normative commitment. It is found that three factors of the employees' motivation and empowerment: operational-autonomy $(\mathrm{p}=0.000)$, open-communication $(\mathrm{p}=0.014)$ and organizational-support $(\mathrm{p}=0.000)$ have a strong impact on normative commitment also but job-challenge $(\mathrm{p}=0.207)$ does not turn out to be the predictor for normative commitment of an employee.

Thus it is evident that the three organizational factors of motivation and empowerment (viz., operational-autonomy, open-communication and organizational-support) influence the employees' moral sense of responsibility towards the organizational objectives that also influences his preference to serve the organization but the assignment of a 'challenging-job' may not drive such moral sense among the employees.

Thus it may be concluded that the predictors: 
operational-autonomy, open-communication and organizational-support had a significant and direct relationship with the all the constituent of organizational-commitment viz., affective, continuance and normative commitment. It is further revealed that although the job-challenge is not significant factor for affecting an employee's continuance and normative commitment but along with other three factors mentioned above, it is a strong predictor of the employees' affective-commitment.

\section{Conclusion and Directions for Further Research}

The study focused on assessing the employees' views concerning the influence of the perceived effectiveness of these factors of motivational-empowerment on various aspects of organizational commitment. Researchers have also emphasized that motivation provides a purpose and direction to the individual behavior and empowerment is concerned with having a role in decision making process (Kreitner, Thorlkson \& Murray [1, 34]). Thus these constructs affect individual performance outcomes and attitudinal outcome behaviors in a prominent manner.

It may be stated that the assignment of a challenging job in accordance with an individual's competency enhances his propensity to generate creative and innovative ideas. The provision of 'operational-autonomy' is associated with an individual's natural inclination for conducting new-experimentations to achieve some newness and novelty. Further, if the organizational environment of an industry is conducive to ensuring 'operational-autonomy', it strengthens an employee's sense of 'self-distinctiveness. Similarly, the 'open-communication' among the employees working across various sections of the plant results in sharing the responsibilities and owning of the organizational outcomes. The internalization of such feeling enhances the employees' sense of 'self-continuity'. Moreover if an organization extends required support at various stages of an individual's creative venture, it definitely enhances his self-esteem and self-efficacy. Thus an employee's positive appreciation for the organizational outcomes of motivational empowerment creates a profound influence on his self-esteem, self-continuity and self-distinctiveness. Another important attitudinal outcome of the motivation and empowerment is the employee's pro-social motivation exhibited through his going above and beyond the call of duty in performing the work (Jha, Grant [26, 47]).

The findings of study indicate that three organizational factors of motivation \& empowerment viz., operational-autonomy, open-communication and organizational-support have positive influence on an individual's choice to stay in the organization (that indicates his continuance-commitment) that is based on extrinsic-considerations but such choice is not influenced by the challenge offered by the specific-job. The analysis further revealed that the situation in case of normative-commitment that is based on employees developing a moral sense of duty towards staying in the organization was also similar and the moral sense of obligation is also not influenced by the 'job-challenge'. However the other three factors that determine an individual's self-worth, self-esteem and self-efficacy are found to be positively associated with developing such moral sense of duty continuing in the organization and fulfilling its goals. In this context it would be relevant to mention that the respondents have mentioned that since all the jobs offered in their organization are challenging in nature, no specific consideration is made in job assignment. If the organizational culture is governed by such conceptual perspective, it is natural that the employees also assign a low priority to 'job-challenge' in context of making a choice for their continuing to serve the organization.

However the affective-commitment that is based on individual's perception regarding the similarities between individuals' own values and the organization values, the situation becomes different. The affective-commitment indicates a stronger bond between employer-employee relationships that is determined by these factors of motivation-empowerment. The findings of the study indicate that according to the employees' perception, all the organizational factors of motivation and empowerment viz., job-challenge, operational-autonomy, open-communication and organizational-support are positively associated with employees' affective commitment.

These findings provide support to the desirability of adopting these organizational measures for enhancing the employees' motivation and empowerment. These initiatives facilitate the creation of an organizational climate conducive to high-commitment management.

The organizational leadership of the automotive industry needs to design appropriate policies and practices and adopt appropriate policy-initiatives that may ensure the employees' participation in decision-making process which could be conducive in generating good working environment and sustainable relationship for managing the employees' commitment.

The study has a further scope of analyzing each and every aspect that distresses the intrinsic motivation of employees towards better commitment. The researchers can also take other variables like leadership styles, job design and managerial standards to enhance the employee's commitment.

\section{REFERENCES}

[1] Kreitner, R. Management, Boston: Houghton Mifflin Company, 1995.

[2] Grant, A.M.. The significance of task significance: Job performance effects, relational mechanisms, and boundary 
conditions, Journal of Applied Psychology, 93, 108-124, 2008a.

[3] Cooper,H., \& Robinson, J.C. The effects of choice on intrinsic motivation and related outcomes: A meta-analysis of research findings, Psychological Bulletin, Vol. 134, 270-300, 2008.

[4] Yazani , B. O., Yaghoubi, N.M, \& Giri, E.S. Factors affecting the empowerment of employees: An empirical study, European Journal of Social Science, 20(2), 267-274, 2011.

[5] Hamed, S.S. Antecedents and Consequences of Employees Empowerment, Management Review: An International Journal, Vol. 5(1), 64-94, 2010.

[6] Naqvi, S.A.H., Hashmi, M.A., Zeeshan, A., \& Shaikh, F.M. Impact of supportive leadership and organizational learning culture as a moderator on the relationship of psychological empowerment and organizational commitment, Australian Journal of Business and Management Research, 1(8), 65-71, 2011.

[7] Sahoo, C.K., Behera, N., \& Tripathy, S.K. Employee empowerment and individual commitment: An analysis from integrative review of research. Employment Relations Record, 10 (1), 40-56, 2010.

[8] Rawat, P. S. Effect of psychological empowerment on commitment of employees: An empirical study. $2^{\text {nd }}$ International Conference on Humanities, Historical and Social Sciences, IPEDR. Vol. 17, IACSIT Press, Singapore, 2011.

[9] Laschinger, H.K.S., Finegan, J.E., Shamian, J. \& Wilk, P. A longitudinal analysis of the impact of workplace empowerment on work satisfaction, Journal of Organizational Behavior. 25, 527-545, 2004.

[10] Bux.S.R. \& Tay, A. The Relationship of Psychological Empowerment, Talent Engagement and Talent Outcomes, International Review of Business Research Papers, 6(1), 215-227, 2010.

[11] ACMA-McKinsey's 'Vision 2015' for the Indian Supplier Industry: how achievable is it?, Online available from https://www.just-auto.com/analysis/how-achievable-is-it_id8 6273.aspx

[12] Automotive Mission Plan (AMP) 2006-16 (A curtain raiser), online available from www.siamindia.com

[13] Jha, P. \& Chakraborty, A. Emerging dynamics of global production networks and labour process: A study from India. Presented at the International Workshop on "New Spatialities and Labour", IGIDR, Mumbai, 2012.

[14] Shore, L. M. \& Martin, H. J. Job satisfaction and organizational commitment in relation to work performance and turnover intentions. Human Relations, 42(7), 625- 638, 1989.

[15] Richard D. Goffin, Ian R. Gellatly, Sampo V. Paunonen, Douglas N. Jackson and John P. Meyer. Criterion Validation of Two Approaches to Performance Appraisal: The Behavioral Observation Scale and the Relative Percentile Method, Journal of Business and Psychology, Vol. 11(1), 23-33, 1996.

[16] Denton, K. Effective Appraisals: Key to Employee Motivation, Industrial Engineering, 19(12), 24-30. 1987.

[17] Ashforth, Blake E., \& Fred, Mael. Social identity theory and the organization, Academy of Management Review, 14 (1), 20-39,1989.
[18] Pratt, M. G. To be or not to be: Central questions in organizational identification. In D. A.Whetten \& P. C. Godfrey (Eds.), Identity in Organizations., Thousand Oaks, CA: Sage, 171-207, 1998.

[19] Manzoor, Q.A. Impact of employees motivation on Organizational effectiveness. Business Management Strategy, 3(1), 1-11, 2012.

[20] Mullins, L.J. \& Peacock, A. Managing through people: Regulating the employment relationship, Administrator, 45-55,1991.

[21] Krikman, B.L. \& Rosen, Benson. Beyond self-management: Antecedents and consequences of team empowerment, Academy of Management Journal, 42(1), 58-74, 1999.

[22] Doughty, H.A. Employee empowerment: Democracy or Delusion?, The Innovation Journal: The Public Sector Innovation Journal, 9(1), 1-24. 2004.

[23] Kuo, Tsung-Hsien, Ho, L.A., Lin, C. \& Lai, K.K. Employee empowerment in a Technology advanced environment, Industrial Management and Data System, 110(1), 24-42, 2009.

[24] Iqbal N., Ahmad, N., Majid M., Naddeem M., Javed K., Zahra A., Ateeq M. Role of employee motivation on employee's commitment in the context of banking sector of D.G.KHAN, Pakistan, Journal of Human Resource Management, 1(1), 1-8, online available from (http://www.sciencepublishinggroup.com/j/jhrm). 2013.

[25] Bogler, R. \& Somech, A. Influence of teacher empowerment on teachers' organizational commitment, professional commitment and organizational citizenship behavior in school, Teaching and Teacher Education, 20, 277-289. 2004.

[26] Jha, S. Influence of Psychological Empowerment on Affective, Normative and Continuance Commitment, A Study in the Indian IT Industry, Journal of Indian Business Research, 3(4), 263-82, 2011.

[27] Mottaz, C.J. Determinants of organizational commitment, Human Relations, 41, 467-482, 1988.

[28] Wong S, S. V., \& Tsang N. The impact of demographic factors on Hong Kong hotel employees' choice of job-related motivators, International Journal Contemp. Hosp. Manage, 11, 230-241, 1999.

[29] Bakay A, Huang J. A. Conceptual model of motivational antecedents of job outcomes and how organizational culture moderates, online available from http://ssrn.com/abstract=1722048. 2010.

[30] Curtis CR, U. R., Severt DE. Employee motivation and organizational commitment: a comparison of tipped and no tipped restaurant employees. Int. J. Hosp. Tourism Adm.,10, 253-269. 2009.

[31] Spreitzer G.M. Psychological Empowerment in the Workplace: Dimensions, Measurement and Validation, Academy of Management Journal, 38(5), 1442-1465, 1995.

[32] Thomas, K.W., \& Velthouse, B.A. Cognitive elements of empowerment, Academy of Management Review, 15, 666-681, 1990.

[33] Kanter, R.M. The change masters, New York: Simon \& Schuster, 1983. 
[34] Thorlkson, A.J. \& Murray, R.P. An empirical study of empowerment in the workplace, Group and Organization Management, Vol. 21(1), 67-83, 1996.

[35] Ongori, H. \& Shunda, W. Managing behind the scenes: employee empowerment, International Journal of Applied Economics and Finance, 20, 1-11.2008.

[36] Judith, M. Z. Employee empowerment and organizational commitment: A study of the food manufacturing sector in Zimbabwe, African Journal of Business Management, 6(38), 10332-10339, 2012.

[37] Frankl, V. Man's search for meaning ( $4^{\text {th }}$ ed.), Boston: Beacon Press, 1992.

[38] Tampoe, M. Motivating knowledge workers-The challenge for the 1990's, Long Range Planning, 26(3), 49-55. 1992.

[39] Liu, Qian \& Lan, Guozhen. The SPSS-based factor analysis and empirical analysis, Science and Technology Information, No.36, 103-105, 2008.

[40] Chen, Ping. Applied Mathematical Statistics, Beijing: China Machine Press, 2008.

[41] Wang, Libin. Multivariate Statistical Analysis: Model, Case, and SPSS, Beijing: Economic Science Press, 2010.

[42] Arthur, J. B. Effects of human resource systems on manufacturing performance and turnover, The Academy of Manufacturing Performance, 37(3), 670-68, 1994.

[43] Steers, R. Antecedents and outcomes of organizational effectiveness, Administrative Science Quarterly, 22, 40-56, 1977.

[44] Chen ZX, Tusi AS, Farh JL, Loyalty to supervisor vs. organizational commitment: Relationships to employee performance in China, Journal of Occupational and Organizational Psychology. 75(3), 339-356, 2002.

[45] Mowday, R.T., Porter, L.W. \& Stress, R.M. The measures of organizational commitment, Journal of Vocational Behaviour, 22 (8), 90-96, 1979.

[46] Allen, N.J. \& Meyer, J.P. A Three-Conceptualization of Organisational Commitment, Human Resource Management Review, 1, 61-89, 1991.

[47] Grant, A.M. Does intrinsic motivation fuel the prosocial fire? Motivational synergy in predicting persistence, performance and productive, Journal of Applied Psychology, 93(1), 48-58, 2008b. 